\title{
Gamma radioactivity levels and their corresponding external exposure of soil samples from tantalite mining areas in Oke-Ogun, South-Western Nigeria
}

\author{
A.K. ADEMOLA ${ }^{1}$, R.I. OBED ${ }^{2}$
}

(Manuscript received 9 September 2011, accepted 16 January 2012)

Abstract

The radioactivity concentrations of ${ }^{226} \mathrm{Ra},{ }^{232} \mathrm{Th}$ and ${ }^{40} \mathrm{~K}$ were measured using gamma-ray spectroscopy with $\mathrm{NaI}$ (TI) detectors in four tantalite mining sites in the Oke-Ogun area, South-Western Nigeria. The measured values of the activities of ${ }^{40} \mathrm{~K},{ }^{226} \mathrm{Ra}$ and ${ }^{232} \mathrm{Th}$ in the soil samples were found to lie in the ranges $123.7 \pm$ 3.8 - 1372.3 \pm 8.6, $16.8 \pm 1.6-71.1 \pm 2.53$ and $3.0 \pm 0.7-31.9 \pm 1.0 \mathrm{~Bq} \mathrm{~kg}^{-1}$, respectively. These samples were also found to have radium equivalent activity in the range 74.2-121.0 Bq kg-1 . Values of $0.2-0.3$ for the external and $0.3-0.4$ for the internal hazard indices were estimated for the samples and the annual effective dose varied from $70.3 \pm 13.5$ to $100.8 \pm 42.8 \mu \mathrm{Sv}$ with a mean of $87.5 \pm 18.6 \mu \mathrm{Sv} \mathrm{y}^{-1}$. The annual effective dose is higher than the world average.

Keywords: Oke-Ogun / radionuclide / tantalite / natural radioactivity / effective dose

\section{Introduction}

Human beings are exposed to background radiation that stems from both natural and man-made sources. Natural background radiation, which is equivalent to $2.4 \mathrm{mSv}$ per person, makes up approximately $80 \%$ of the total radiation to which a person is exposed during one year (IAEA, 1996). Most of the radioactivity in the terrestrial environment, whether it is natural or man-made, is bound to the components of the soil. Transportation of this radioactivity from soil to vegetation is possible via dust deposition or root uptake and then to humans through inhalation, breathing and soil ingestion. Therefore, all pathways of exposure that originate from soil are potentially important for the purpose of radiation risk assessment. The two prominent sources of external radiation are cosmic rays and terrestrial gamma rays. Terrestrial gamma rays are essentially due to radionuclides belonging to the ${ }^{238} \mathrm{U}$ and ${ }^{232} \mathrm{Th}$ series and singly occurring ${ }^{40} \mathrm{~K}$ that are present in the earth's crust.

\footnotetext{
1 Department of Physical Sciences, Bells University of Technology, Ota Nigeria.

2 Department of Physics, University of Ibadan, Nigeria.
} 
In the last two decades, many studies have been carried out on the natural background and artificial radiation levels in Nigeria (Oresegun et al., 1990; Obed et al., 2005; Jibiri et al., 1998; Jibiri et al., 2011; Farai et al., 2006; Ademola et al., 2006).

The Oke-Ogun area is naturally endowed with a variety of minerals, especially tantalite, iron ore, marble and aquamarine, which contribute enormously to the economic progress of the region. These stones are of granite type and may contain a relatively high concentration of natural radioactivity. So, with a lot of mining activities taking place in this area, there is the possibility of high background radiation in this area. Also, the representative gamma irradiation may be indirectly transferred to dwellings, thereby creating a radioactive environment due to indoor radon. Therefore, there is a need to carry out a survey of background radiation in these mining sites to yield data that may be used to assess the health effects on the population.

The present study was designed to enhance the existing information on radioactivity in mining sites. The objectives of the present study are therefore: (i) determination of activity concentrations of ${ }^{226} \mathrm{Ra},{ }^{232} \mathrm{Th}$ and ${ }^{40} \mathrm{~K}$ in the representative soil samples; (ii) determination of the internal $\left(H_{\mathrm{in}}\right)$ and external $\left(H_{\mathrm{ex}}\right)$ radiological hazard indices, radium equivalent $\left(R a_{\mathrm{eq}}\right)$, absorbed dose rate (D), and the representative gamma index $\left(I_{\gamma \mathrm{r}}\right)$ of the representative soil samples, and (iii) estimation of the effective dose.

\section{Geology of the study area}

The study area, Oke-Ogun, is located in the North-Western part of Oyo State, Nigeria, and is bounded by River Ogun (Fig. 1). The geographical location of this area is $\left(38^{\circ} 35^{\prime}-48^{\circ} 13^{\prime} \mathrm{E}, 88^{\circ} 05^{\prime}-98^{\circ} 08^{\prime} \mathrm{N}\right)$. The area is between 277 and $456 \mathrm{~m}$ above sea level within the Pre-Cambrian Basement Complex of South-Western Nigeria and is at the fringes of the border between Nigeria and the Republic of Benin. Geologically, the study area is underlain by the Pre-Cambrian Basement Complex, composed of magnatite, gneiss and schist, which extends from Iseyin to Kisi in the far north. The major rock unit in the study area is the undifferentiated meta-sediments in addition to granite, granitegneiss and porphyritic granite. However, syenites are common and well exposed within and around Saki and Okeho in the study area, while there is occurrence of several pegmatite veins, as intrusion into the undifferentiated crystalline basement rocks, most of which are in gemstones, especially tourmaline (Tijani et al., 2003). Apart from the small hills and inselbergs, the bedrocks are generally covered by the weathered regolith usually composed of clay and sandy soils, which are lateritized in places, depending on the underlying bedrock types. The mineral deposits in the region include tantalite in Atisbo, Iwajowa, Iseyin and Itesiwaju districts, amphibolites in Atisbo, Kajola, Saki East and Saki West, Kaolin in Iseyin, Saki East and Saki West, gemstones in Saki 


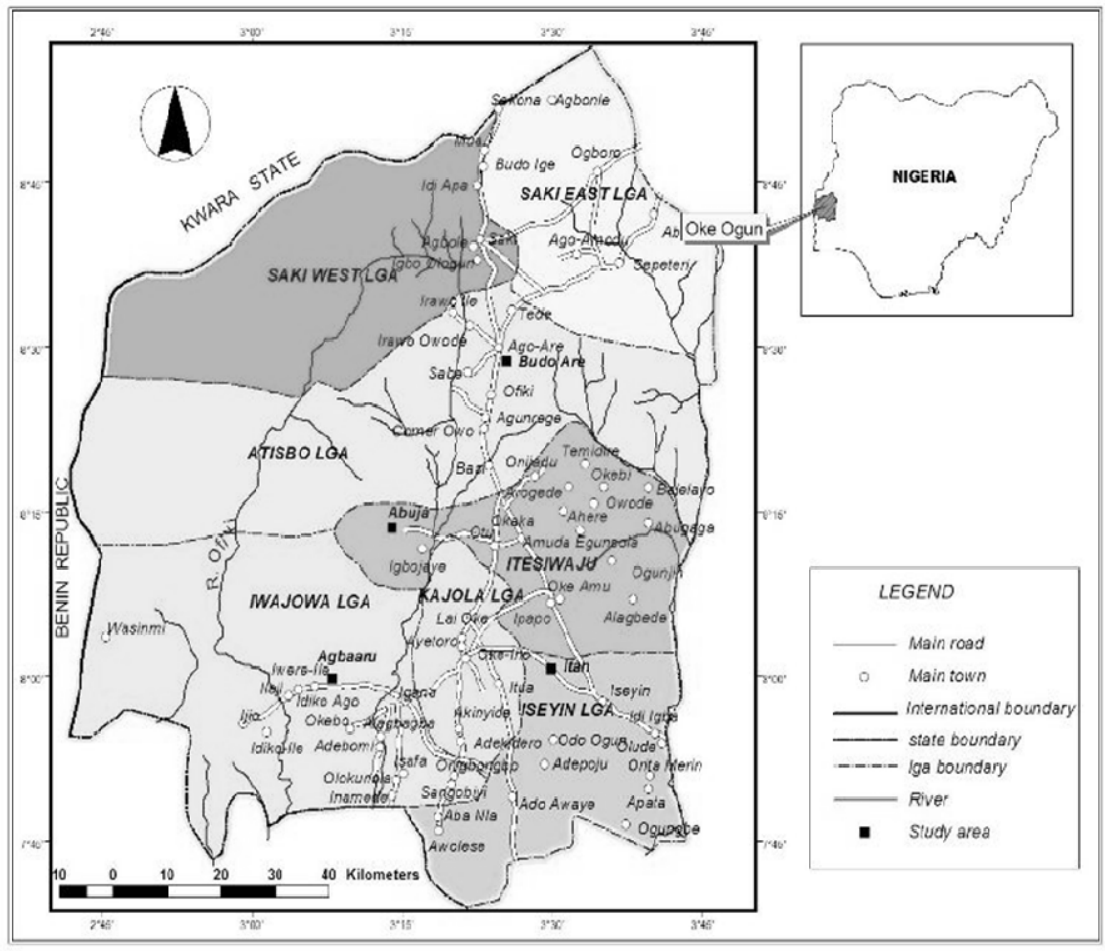

Figure 1 - Map of the Oke-Ogun area in Nigeria and localization of investigation sampling points.

West, Saki East, Atisbo, Itesiwaju and Kajola districts, and granites, sand and gravel in all the districts. These stones are of granite type and may contain a relatively high concentration of natural radioactivity.

\section{Materials and methods}

\subsection{Sample collection and processing}

Soil samples were collected from four tantalite mining sites in the Oke-Ogun area (Fig. 1). Ten samples were collected from each mine about $500 \mathrm{~cm}$ apart to allow an even collection of the soil samples. The samples were collected at a depth of about $20-30 \mathrm{~cm}$ at the various locations. The samples were processed following the standard procedures (EML Procedure Manual, 1983). Soil samples were well mixed after removing extraneous materials such as roots, pieces of stones and 
gravel. Samples were weighed and then dried in an oven at $105{ }^{\circ} \mathrm{C}$ overnight and re-weighed to find the water content. The samples were crunched and were made to pass through a $0.2-\mathrm{mm}$ sieve. Sieved samples were weighed and a mass of $200 \mathrm{~g}$ of each sample was placed in a plastic container $(6.5 \mathrm{~cm}$ in diameter and $7.0 \mathrm{~cm}$ in height). The plastic containers were hermetically sealed with adhesive tape (AERB, 2003) for $30 \mathrm{~d}$, which is enough for secular equilibrium to take place (Olomo et al., 1994).

\subsection{Activity determination}

Analysis of radionuclide concentrations was performed by gamma-ray spectrometry with sodium iodide detectors. The counting assembly was a scintillation detector and a Canberra multi-channel analyzer. The detector was a 7.6-7.6 $\mathrm{cm}^{2} \mathrm{NaI}(\mathrm{Tl})$ manufactured by Bicron. A cylindrical lead shield of approximately $5 \mathrm{~cm}$ thickness with a fixed bottom and a movable cover shielded the detector from background radiation. The spectrometer was tested for its linearity and then calibrated for energy using gamma sources supplied by the International Atomic Energy Agency, Vienna. The detection efficiency calibration of the system was carried out using a reference standard gamma source prepared by Rocketdyne Laboratories, Canoga Park, CA, USA, which is traceable to a mixed standard gamma source (No. 48722-356) by Atlantic Inc., Atlanta, GA, USA. The detector assembly has a resolution of $\sim 8 \%$ at $0.662 \mathrm{MeV}$ of ${ }^{137} \mathrm{Cs}$. The reference sources have activity concentration of $479.15,566.47$ and $11.60 \mathrm{~Bq}$ for ${ }^{40} \mathrm{~K},{ }^{226} \mathrm{Ra}$ and ${ }^{232} \mathrm{Th}$, respectively.

The background count was determined by counting an empty container of the same dimensions as the one containing the samples and subtracting from the gross count. The counting time was set at $36000 \mathrm{~s}(10 \mathrm{~h})$ to obtain the gamma spectrum with good statistics.

From the net area, the activity concentrations in the samples were obtained using equation (1):

$$
C\left(\mathrm{~Bq} \mathrm{~kg}^{-1}\right)=k C_{n}
$$

where

$$
k=1 / \varepsilon P_{\gamma} M_{S},
$$

$C$ is the activity concentration of the radionuclide in the sample given in $\mathrm{Bq} \mathrm{kg}^{-1}$, $C_{n}$ is the count rate under the corresponding peak, $\varepsilon$ is the detector efficiency at the specific $\gamma$-ray energy, $P_{\gamma}$ is the absolute transition probability of the specific $\gamma$-ray, and $M_{s}$ is the mass of the sample $(\mathrm{kg})$. 
GAMMA RADIOACTIVITY LEVELS AND THEIR CORRESPONDING EXTERNAL EXPOSURE...

TABLE I

Activity concentrations of ${ }^{226} \mathrm{Ra},{ }^{232} \mathrm{Th}$ and ${ }^{40} \mathrm{~K}\left(\mathrm{Bqkg}^{-1}\right)$ in mining sites of the Oke-Ogun area.

\begin{tabular}{cccc}
\hline Sites & ${ }^{226} \mathrm{Ra}$ & ${ }^{232} \mathrm{Th}$ & ${ }^{40} \mathrm{~K}$ \\
\hline Itan, Iseyin & $41.3 \pm 12.3$ & $19.1 \pm 2.7$ & $153.0 \pm 16.5$ \\
\hline Budo-Are Ofiki & $42.1 \pm 12.7$ & $16.4 \pm 4.6$ & $541.7 \pm 372.5$ \\
\hline Agbaaru, Iwere-Ile & $40.3 \pm 28.6$ & $15.7 \pm 8.9$ & $506.6 \pm 361.1$ \\
Abuja, Komu & $35.4 \pm 7.5$ & $19.1 \pm 3.0$ & $335.6 \pm 121$ \\
Mean & $39.8 \pm 3.0$ & $17.7 \pm 1.8$ & $384.2 \pm 178.5$ \\
\hline
\end{tabular}

The detection limit of a measuring system describes its operating capability without the influence of the sample. The detection limit (DL) given in $\mathrm{Bq} \mathrm{kg}^{-1}$, which is required to estimate the minimum detectable activity in a sample, was obtained using equation (2):

$$
\mathrm{LLD}=4.65 \sqrt{C_{b} / t_{b}} \times f
$$

where $C_{b}$ is the net background count in the corresponding peak, $t_{b}$ is the background counting time (s), and $f$ is the factor that converts cps (counts per second) to activity concentration $\left(\mathrm{Bq} \mathrm{kg}^{-1}\right)$.

The detection limits obtained were $17.3 \mathrm{~Bq} \mathrm{~kg}^{-1}, 4.2 \mathrm{~Bq} \mathrm{~kg}^{-1}$ and $5.1 \mathrm{~Bq} \mathrm{~kg}^{-1}$ for ${ }^{40} \mathrm{~K},{ }^{226} \mathrm{Ra}$ and ${ }^{232} \mathrm{Th}$, respectively. Values below these numbers were taken as being below the detection limit.

The concentration of ${ }^{226} \mathrm{Ra}$ was determined by a $1.764 \mathrm{MeV}$ gamma ray from ${ }^{214} \mathrm{Bi}$. The gamma-ray energy of $2.614 \mathrm{MeV}$ from ${ }^{208} \mathrm{Tl}$ was used to determine the activity concentration of ${ }^{232} \mathrm{Th}$ and a gamma ray of $1.460 \mathrm{MeV}$ from ${ }^{40} \mathrm{~K}$ was used to determine the concentration of ${ }^{40} \mathrm{~K}$ in the samples.

\section{Results and discussions}

The results of activity measurements are presented in Table I. ${ }^{226} \mathrm{Ra}$ concentration varied in the range $16.8 \pm 1.6-71.1 \pm 2.5 \mathrm{~Bq} \mathrm{~kg}^{-1}$ with arithmetic mean \pm standard deviation $(\mathrm{AM} \pm \mathrm{SD})$ of $39.8 \pm 3.0 \mathrm{~Bq} \mathrm{~kg}^{-1},{ }^{232} \mathrm{Th}$ in the range of below the detection limit $3.0 \pm 0.7-31.9 \pm 1.0 \mathrm{~Bq} \mathrm{~kg}^{-1}$ with a mean of $17.7 \pm 2.5 \mathrm{~Bq} \mathrm{~kg}^{-1}$ and ${ }^{40} \mathrm{~K}$ in the range of $123.7 \pm 3.8-1372.3 \pm 81.6 \mathrm{~Bq} \mathrm{~kg}^{-1}$ with a mean of $384.2 \pm$ $178.5 \mathrm{~Bq} \mathrm{~kg}^{-1}$. The activity concentration of ${ }^{40} \mathrm{~K}$ was lowest in Itan, Iseyin mining site $\left(153 \pm 16.5 \mathrm{~Bq} \mathrm{~kg}^{-1}\right)$ and highest in Budo-Are, Ofiki $\left(541.7 \pm 372.5 \mathrm{~Bq} \mathrm{~kg}^{-1}\right)$. The high concentration of ${ }^{40} \mathrm{~K}$ in Ofiki may be due to extensive farming activities involving the use of fertilizers. The mean activity concentration of ${ }^{226} \mathrm{Ra}$ 
TABLE II

The absorbed dose rate of soil samples in mining sites of the Oke-Ogun area (nGy $\left.\mathbf{h}^{-1}\right)$.

\begin{tabular}{ccc}
\hline Sites & Absorbed Dose Rate in Air $\left(\mathrm{nGy} \mathrm{h}^{-1}\right)$ \\
\hline Itan, Iseyin & $38.2 \pm 5.5$ & $(34.0 \pm 0.9-51.8 \pm 0.9)$ \\
\hline Budo-Are Ofiki & $54.8 \pm 17.4 \quad(31.0 \pm 0.8-87.7 \pm 1.0)$ \\
\hline Agbaaru, Iwere-Ile & $52.7 \pm 19.8 \quad(23.5 \pm 0.8-77.0 \pm 1.0)$ \\
\hline Abuja, Komu & $44.5 \pm 11.1 \quad(29.8 \pm 0.8-74.5 \pm 1.0)$ \\
Mean & $47.6 \pm 7.7$ \\
\hline
\end{tabular}

was highest in Budo-Are, Ofiki $\left(42.1 \pm 12.7 \mathrm{~Bq} \mathrm{~kg}^{-1}\right)$ and lowest in Abuja, Komu $\left(35.4 \pm 7.5 \mathrm{~Bq} \mathrm{~kg}^{-1}\right)$. The mean activity concentration of ${ }^{232} \mathrm{Th}$ was highest in Abuja, Komu $\left(19.1 \pm 3.0 \mathrm{~Bq} \mathrm{~kg}^{-1}\right)$ and lowest in Agbaaru, Iwere-Ile $\left(15.7 \pm 8.9 \mathrm{~Bq} \mathrm{~kg}^{-1}\right)$.

\subsection{Absorbed dose rates}

From the results of ${ }^{226} \mathrm{Ra},{ }^{232} \mathrm{Th}$ and ${ }^{40} \mathrm{~K}$ activities in Table I, the gamma dose rates in air were calculated using the dose coefficients $\left(\mathrm{nGy} \mathrm{h}^{-1}\right.$ per Bq kg$\left.{ }^{-1}\right) 0.462$, 0.604 and 0.0417 given in UNSCEAR (2000) for ${ }^{226} \mathrm{Ra}$ sub-series, ${ }^{232} \mathrm{Th}$ series and ${ }^{40} \mathrm{~K}$, respectively. The absorbed dose is given by equation (3):

$$
D=0.446 A_{\mathrm{Ra}}+0.662 A_{\mathrm{Th}}+0.048 A_{\mathrm{K}}
$$

where $D$ is the dose rate $\left(\mathrm{nGy} \mathrm{h}^{-1}\right)$ at $1 \mathrm{~m}$ above the ground due to ${ }^{226} \mathrm{Ra},{ }^{232} \mathrm{Th}$ and ${ }^{40} \mathrm{~K}$ in the soil sample. $A_{\mathrm{Ra}}, \mathrm{A}_{\mathrm{Th}}$ and $A_{\mathrm{K}}$ are the activity concentrations of ${ }^{226} \mathrm{Ra}$, ${ }^{232} \mathrm{Th}$ and ${ }^{40} \mathrm{~K}_{\text {in } \mathrm{Bq} \mathrm{kg}}{ }^{-1}$, respectively.

The absorbed dose values thus calculated are presented in Table II. The total absorbed dose delivered by these radionuclides ranged from $23.5 \pm 0.8-87.7 \pm$ $1.0 \mathrm{nGy} \mathrm{h}^{-1}$ with a mean of $47.6 \pm 7.7 \mathrm{nGy} \mathrm{h}^{-1}$, which is lower than the world average value of $51 \mathrm{nGy} \mathrm{h}^{-1}$ (UNSCEAR, 2000). The annual effective dose to the population due to the soil activity was estimated using the dose coefficient $(0.7 \mathrm{~Sv}$ $\mathrm{Gy}^{-1}$ ) and occupancy factor (0.2) for outdoors given in UNSCEAR (2000). The average effective dose (Tab. III) varies in the range $70.3 \pm 13.5$ in Itan, Iseyin to $100.8 \pm 42.8 \mu \mathrm{Sv}$ in Budo-Are, Ofiki, with a mean annual effective dose of $87.5 \pm$ $18.6 \mu \mathrm{Sv} \mathrm{y}^{-1}$, which is about $25 \%$ higher than the world average of $70 \mu \mathrm{Sv} \mathrm{y}^{-1}$ (UNSCEAR, 2000). 
TABLE III

Effective dose estimated in mining sites of the Oke-Ogun area.

\begin{tabular}{cc}
\hline Sites & Mean Effective dose $\left(\mu S v \mathrm{y}^{-1}\right)$ \\
\hline Itan, Iseyin & $70.3 \pm 13.5$ \\
Budo-Are Ofiki & $100.8 \pm 42.8$ \\
\hline Agbaaru, Iwere-Ile & $96.7 \pm 48.1$ \\
Abuja, Komu & $81.9 \pm 37.1$ \\
Mean & $87.5 \pm 18.6$ \\
\hline
\end{tabular}

TABLE IV

Radium Equivalent $\left(R a_{\mathrm{eq}}\right)$, the external hazard index, $\left(H_{\mathrm{ex}}\right)$, internal hazard index $\left(H_{\mathrm{in}}\right)$ and gamma index $\left(I_{\gamma \mathbf{r}}\right)$ in the tantalite mining sites.

\begin{tabular}{ccccc}
\hline Sites & $\begin{array}{c}\text { Radium Equivalent } \\
\left(\mathrm{Bq} \mathrm{kg}^{-1}\right)\end{array}$ & $\begin{array}{c}\text { External Hazard } \\
\text { Index }\left(H_{e x}\right)\end{array}$ & $\begin{array}{c}\text { Internal Hazard } \\
\text { Index }\left(H_{\text {in }}\right)\end{array}$ & Gamma Index $\left(I_{\gamma r}\right)$ \\
\hline Itan, Iseyin & $79.9 \pm 12.3$ & 0.2 & 0.4 & 0.6 \\
Budo-Are Ofiki & $113.2 \pm 29.1$ & 0.3 & 0.4 & 0.8 \\
Agbaaru, Iwere-Ile & $102.8 \pm 36.7$ & 0.3 & 0.4 & 0.8 \\
Abuja, Komu & $88.5 \pm 23.3$ & 0.2 & 0.3 & 0.7 \\
Mean & $96.1 \pm 14.8$ & 0.3 & 0.4 & 0.7 \\
\hline
\end{tabular}

\subsection{Radium equivalent, internal hazard, external hazard and gamma index}

The radium equivalent activity, internal hazard index and external hazard index are presented in Table IV. The radium equivalent activity is calculated from equation (4) (UNSCEAR, 1982) and it ranged from $79.9 \pm 12.3$ to $113.2 \pm$ $29.1 \mathrm{~Bq} \mathrm{~kg}^{-1}\left(\right.$ mean $\left.=96.1 \pm 14.8 \mathrm{~Bq} \mathrm{~kg}^{-1}\right)$ :

$$
R a_{\mathrm{eq}}=A_{\mathrm{Ra}}+1.43 A_{\mathrm{Th}}+0.077 A_{\mathrm{K}}
$$

where $A_{\mathrm{Ra}}, A_{\mathrm{Th}}$ and $A_{\mathrm{K}}$ are the activity concentrations in $\mathrm{Bq} \mathrm{kg}{ }^{-1}$ of ${ }^{226} \mathrm{Ra},{ }^{232} \mathrm{Th}$ and ${ }^{40} \mathrm{~K}$, respectively.

The current regulation is that $R a_{\mathrm{eq}}$ should be inferior to $370 \mathrm{~Bq} \mathrm{~kg}^{-1}$ for any material that will be used in building of dwellings (UNSCEAR, 1982). It is assumed that $370 \mathrm{~Bq} \mathrm{~kg}^{-1}$ of ${ }^{226} \mathrm{Ra}, 259 \mathrm{~Bq} \mathrm{~kg}^{-1}$ of ${ }^{232} \mathrm{Th}$ and $4810 \mathrm{~Bq} \mathrm{~kg}^{-1}$ of ${ }^{40} \mathrm{~K}$ produce the same gamma-ray dose rate (Straden, 1979). The mean radium equivalents obtained are presented in Table IV. 
To limit the external gamma-radiation dose from building materials, the external hazard index $\left(H_{\mathrm{ex}}\right)$ was calculated from equation (5) (Beretka et al., 1985):

$$
H_{\mathrm{ex}}=\frac{A_{\mathrm{Ra}}}{370}+\frac{A_{\mathrm{Th}}}{259}+\frac{A_{\mathrm{K}}}{4810} \leq 1 .
$$

The calculated mean external hazard index in the present study is 0.3 , which is much lower than unity, as desirable.

To assess the radiation hazard due to internal exposure from radon and its short-lived decay products to the respiratory organs, the internal exposure to radon and its decay products is quantified by the internal hazard index $\left(H_{\mathrm{in}}\right)$, which is given in equation (6) (Beretka et al., 1985):

$$
H_{\mathrm{in}}=\frac{A_{\mathrm{Ra}}}{185}+\frac{A_{\mathrm{Th}}}{259}+\frac{A_{\mathrm{K}}}{4810} \leq 1 .
$$

The internal hazard index $\left(H_{\text {in }}\right)$ for soil calculated in this study ranged from 0.3 to 0.4 with a mean of 0.4 , which is lower than unity, as desirable.

According to the European Commission, the gamma activity concentration index $\left(I_{\gamma \mathrm{r}}\right)$ is derived to identify whether a dose standard is met $(\mathrm{EC}, 1999)$ and is estimated from equation (7):

$$
I_{\gamma \mathrm{r}}=\frac{A_{\mathrm{Ra}}}{150}+\frac{A_{\mathrm{Th}}}{100}+\frac{A_{\mathrm{K}}}{1500} .
$$

The index $I_{\gamma \mathrm{r}}$ is correlated with the annual dose due to the excess external gamma radiation caused by external material. Values of the index $I_{\gamma \mathrm{r}}=1$ correspond to $0.3 \mathrm{mSv} \mathrm{y}^{-1}$. Thus, the activity concentration index $I_{\gamma \mathrm{r}}$ should be used only as a screening tool for identifying materials which might be of concern to be used as the covering material (Al-Saleh et al., 2007). The index $I_{\gamma \mathrm{r}}$ estimated is 0.7 , which is less than unity.

Table V compares the results of this study with those obtained in other parts of the country. The mean activity concentrations of ${ }^{40} \mathrm{~K},{ }^{232} \mathrm{Th}$ and ${ }^{226} \mathrm{Ra}$ in this study were $384.6 \pm 178.5,17.7 \pm 1.8$ and $39.8 \pm 3.0 \mathrm{~Bq} \mathrm{~kg}^{-1}$, respectively. These values were lower than the world average of 400 and $30 \mathrm{~Bq} \mathrm{~kg}^{-1}$ for ${ }^{40} \mathrm{~K}$ and ${ }^{232} \mathrm{Th}$, respectively, but slightly higher for ${ }^{226} \mathrm{Ra}\left(35 \mathrm{~Bq} \mathrm{~kg}^{-1}\right)$. These values were also higher than those obtained in Ibadan and Lagos in the South-West, South-Eastern cities and Southern cities but lower than the results obtained in Abeokuta and Akure in the South-Western Zone, North-East, North-West and North Central cities (Obed et al., 2005; Ademola et al., 2010). The calculated mean absorbed dose rate in air was $47.6 \pm 7.7 \mathrm{nGy} \mathrm{h}^{-1}$. This is lower than the zonal mean of $51 \pm$ $48 \mathrm{nGy} \mathrm{h}^{-1}$ obtained for the South-Western zone (Obed et al., 2005). The mean 
GAMMA RADIOACTIVITY LEVELS AND THEIR CORRESPONDING EXTERNAL EXPOSURE...

TABLE V

Comparison of the calculated results with those obtained from other parts of the country.

\begin{tabular}{|c|c|c|c|c|c|c|}
\hline References & Area & $\begin{array}{c}\left.{ }^{226} \mathrm{Ra}^{(\mathrm{Bq} \mathrm{kg}} \mathrm{kg}^{-1}\right)\end{array}$ & $\begin{array}{c}{ }^{232} \mathrm{Th} \\
\left(\mathrm{Bq} \mathrm{kq}^{-1}\right)\end{array}$ & $\left.\begin{array}{c}{ }^{40} \mathrm{~K} \\
(\mathrm{~Bq} \mathrm{~kg} \\
-1\end{array}\right)$ & $\begin{array}{l}\text { Absorbed } \\
\text { dose rate } \\
\left(\mathrm{nGy} \mathrm{h}^{-1}\right)\end{array}$ & $\begin{array}{c}\text { Annual } \\
\text { Effective } \\
\text { dose }(\mu \mathrm{Sv})\end{array}$ \\
\hline Present Study & Oke-Ogun & $39.8 \pm 3.0$ & $17.7 \pm 1.8$ & $384.2 \pm 178.5$ & $47.6 \pm 7.7$ & $87.5 \pm 18.6$ \\
\hline Obed et al., 2005 & Onitsha & $31 \pm 9$ & $13 \pm 4$ & $93 \pm 36$ & $26 \pm 4$ & 31.9 \\
\hline Obed et al., 2005 & Abeokuta & $43 \pm 15$ & $84 \pm 57$ & $329 \pm 175$ & $88 \pm 44$ & 107.9 \\
\hline $\begin{array}{c}\text { Ademola et al., } \\
2010\end{array}$ & Ondo & $13.3 \pm 8.0$ & $40.0 \pm 10.2$ & $240.2 \pm 133.5$ & $41.5 \pm 8,5$ & $50.7 \pm 10.9$ \\
\hline Obed et al., 2005 & Warri & $33 \pm 8$ & $7 \pm 3$ & $87 \pm 48$ & $20 \pm 7$ & 25.8 \\
\hline Obed et al., 2005 & Bauchi & $35 \pm 11$ & $24 \pm 11$ & $961 \pm 287$ & $71 \pm 18$ & 87.1 \\
\hline UNSCEAR, 2000 & World Average & 35 & 30 & 400 & 54 & 70 \\
\hline
\end{tabular}

annual effective dose in the study area was estimated as $87.5 \pm 18.6 \mu \mathrm{Sv} \mathrm{y}^{-1}$. This value for the effective dose is about $25 \%$ higher than the world average of $70 \mu \mathrm{Sv}$ (UNSCEAR, 2000) and is also higher than the average of $62.9 \mu \mathrm{Sv}$ obtained for South-Western cities in Nigeria (Farai et al., 2006).

\section{Conclusions}

Although the study did not cover the entire country, this is the first report on radionuclide data in soil of the Oke-Ogun area, Nigeria. The environmental monitoring of natural background radiation in Oke-Ogun using sodium iodide detectors revealed the distribution of the natural radiation level in all the soil samples measured. From the results obtained, the distribution of radionuclide was not uniform. Also, no artificial radionuclide was detected in any of the measured soil samples.

The measured values of the activities of ${ }^{40} \mathrm{~K},{ }^{226} \mathrm{Ra}$ and ${ }^{232} \mathrm{Th}$ in the soil samples were found to lie in the ranges $123.7 \pm 3.8-1372.3 \pm 8.6,16.8 \pm 1.6-$ $71.1 \pm 2.53$ and $3.0 \pm 0.7-31.9 \pm 1.0 \mathrm{~Bq} \mathrm{~kg}^{-1}$, respectively. These samples were also found to have radium equivalent activity in the range $74.2-121.0 \mathrm{~Bq} \mathrm{~kg}^{-1}$. Samples were found to have values of $0.2-0.3$ for the external and $0.3-0.4$ for the internal hazard indices. The annual effective dose rate in air varied from $70.3 \pm 13.5$ to $100.8 \pm 42.8 \mu \mathrm{Sv}$ with a mean of $87.5 \pm 18.6 \mu \mathrm{Sv} \mathrm{y}^{-1}$. The estimated representative $\left(I_{r}\right)$ hazard index is 0.7 . The annual effective dose is higher than the world average (UNSCEAR, 2000). 


\section{REFERENCES}

Ademola J.A., Farai I.P. (2006) Gamma activity and radiation dose in concrete building blocks used for construction of dwellings in Jos, Nigeria. Radiat. Prot. Dosim. 121, 395-405.

Ademola J.A., Ademonehin S. (2010) Radioactivity concentrations and dose assessment for bitumen and soil samples around bituminous deposit in Ondo state, Nigeria. Radioprotection 45, 359368.

Al-Saleh F.S., Al-Berzan B. (2007) Measurements of natural radioactivity in some kinds of marble and granite used in Riyadh region. J. Nucl. Radiat. Phys. 2, 25-36.

Atomic Energy Regulatory Board (2003) Accreditation of laboratories for measurement of radionuclide content in commodities (Mumbai, India: Atomic Energy Regulatory Board).

Beretka J., Mathew P.J. (1985) Natural radioactivity in Australian building materials, industrial waste and by-product. Health Phys. 48, 87-95.

European Commission (1999) Report on Radiological Protection Principles Concerning the Natural Radioactivity of Building Materials. Directorate-General Environment, Nuclear safety and civil protection. Radiation Protection 112, 1-16.

EML Procedure Manual (1983) Volchok, Herbert L., de Planque, Gail (Eds.), twentysixth ed. New York, US Department of Energy, Environmental Measurement Laboratory.

Farai I.P., Obed R.I., Jibiri N.N. (2006) Soil radioactivity and incidence of cancer in Nigeria. $J$. Environ. Radioactiv. 90, 29-36.

International Atomic Energy Agency (IAEA, 1996) Radiation Safety. Regulation for the safe transport of radioactive material. IAEA Division of Public Information, 96-00725 IAEA/PI/A47E.

Jibiri N.N., Farai I.P. (1998) Assessment of dose rate and collective effective dose equivalent due to terrestrial gamma radiation in the city of Lagos, Nigeria; Radiat. Prot. Dosim. 76, 191-194.

Jibiri N.N., Esen N.U. (2011) Radionuclide contents and radiological risk to the population due to raw materials and soil samples from the mining sites of quality ceramic and pottery industries in Akwa Ibom, Nigeria, Radioprotection 46, 75-87.

Obed R.I., Farai I.P. Jibiri N.N. (2005) Population dose distribution due to soil radioactivity concentration levels in 18 cities across in Nigeria. J. Radiol. Prot. 25, 305-312.

Olomo J.B., Akinloye M.K., Balogun F.A. (1994) Distribution of gamma-emitting natural radionuclide in soil and water around nuclear research establishment, Ile-Ife Nigeria. Nucl. Instrum. Meth. A 353, 553-557.

Oresegun M.O., Babalola I.A. (1990) Occupational radiation exposure associated with milling of ThU rich soils in Nigeria. Health Phys. 58, 213-215.

Sources and Effects of Ionizing Radiation. Report of the United Nations Scientific Committee on the Effects of Atomic Radiation to the General Assembly. United Nations, New York.

Straden E. (1979). Radioactivity of building materials and the gamma radiation in dwellings. Phys. Med. Biol. 24, 921-930.

Taskin H., Karavus M., Ayb B., Topuzoglu A., Hidiroglu S., Karahan G. (2009) Radionuclide concentrations in soil and lifetime cancer risk due to gamma radioactivity in Kirklareli, Turkey, J. Environ. Radioactiv. 100, 49-53.

Tijani M.N., Abimbola A.F. (2003) Groundwater chemistry and isotopes studies of weathered basement aquifer: a case study of Oke-Ogun area, S.W. Nigeria. Afr. Geosci. Rev. 10, 373-387.

United Nations Scientific Committee on the Effects of Atomic Radiation (UNSCEAR, 1982) Ionizing radiation: sources and biological effects (New York: United Nations) E.82.IX.8.

United Nations Scientific Committee on the Effects of Atomic Radiation (UNSCEAR, 2000). 